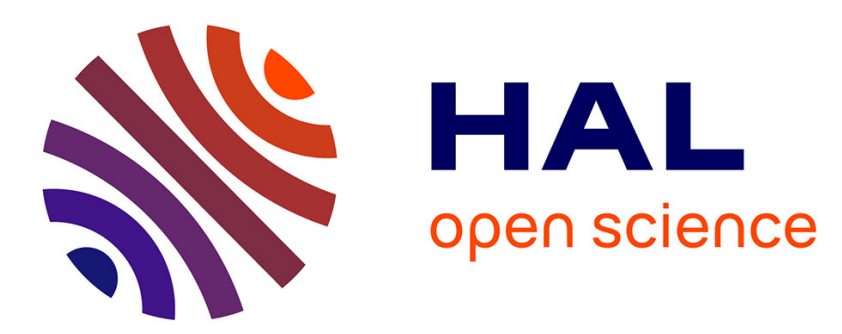

\title{
Fuel cell rejuvenation of hygrothermally aged Nafion
}

Floraine Collette, Francette Thominette, Sylvie Escribano, Angèle Ravachol, Arnaud Morin, Gérard Gebel

\section{To cite this version:}

Floraine Collette, Francette Thominette, Sylvie Escribano, Angèle Ravachol, Arnaud Morin, et al.. Fuel cell rejuvenation of hygrothermally aged Nafion. Journal of Power Sources, 2012, 202, pp.126133. 10.1016/j.jpowsour.2011.10.135 . hal-01190801

\section{HAL Id: hal-01190801 https://hal.science/hal-01190801}

Submitted on 1 Sep 2015

HAL is a multi-disciplinary open access archive for the deposit and dissemination of scientific research documents, whether they are published or not. The documents may come from teaching and research institutions in France or abroad, or from public or private research centers.
L'archive ouverte pluridisciplinaire HAL, est destinée au dépôt et à la diffusion de documents scientifiques de niveau recherche, publiés ou non, émanant des établissements d'enseignement et de recherche français ou étrangers, des laboratoires publics ou privés. 


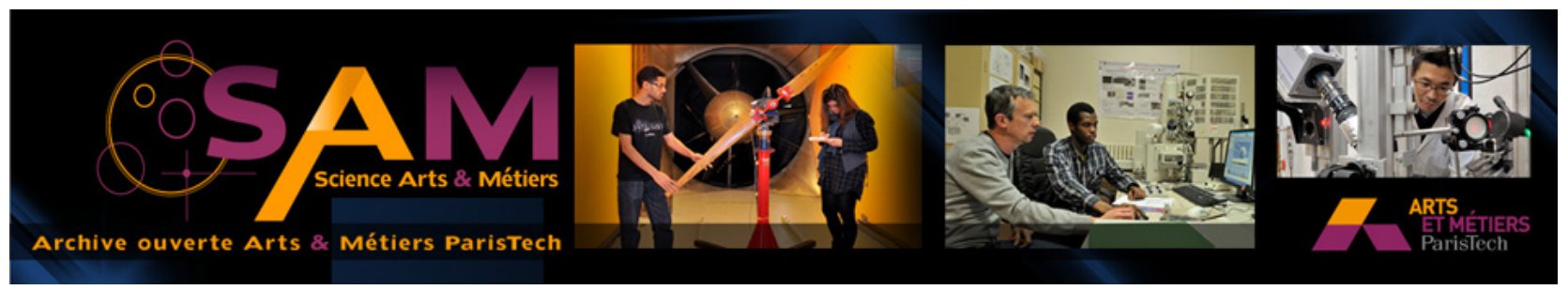

Science Arts \& Métiers (SAM)

is an open access repository that collects the work of Arts et Métiers ParisTech researchers and makes it freely available over the web where possible.

This is an author-deposited version published in: http://sam.ensam.eu

Handle ID: .http://hdl.handle.net/10985/9886

\section{To cite this version :}

Floraine COLLETTE, Francette THOMINETTE, Sylvie ESCRIBANO, Angèle RAVACHOL, Arnaud MORIN, Gérard GEBEL - Fuel cell rejuvenation of hygrothermally aged Nafion - Journal of Power Sources - Vol. 202, p.126- 133 - 2012 


\title{
Fuel cell rejuvenation of hygrothermally aged Nafion ${ }^{\circledR}$
}

\author{
Floraine M. Collette ${ }^{\mathrm{a}}$, Francette Thominette ${ }^{\mathrm{a}}$, Sylvie Escribano ${ }^{\mathrm{b}}$, \\ Angèle Ravachol $^{\mathrm{b}}$, Arnaud Morin ${ }^{\mathrm{b}}$, Gérard Gebel ${ }^{\mathrm{c}, *}$ \\ a Laboratoire d'Ingénierie des Matériaux, ENSAM, 151 Boulevard de l'Hôpital, 75013 Paris, France \\ ${ }^{\mathrm{b}}$ DRT/Liten/DEHT/LCPEM, CEA-Grenoble, 17 rue des Martyrs Cedex 9, F-38054 Grenoble, France \\ ${ }^{\mathrm{c}}$ Laboratoire Structure et Propriétés des Architectures Moléculaires, UMR 5819 SPrAM CEA-CNRS-UJF, INAC, CEA Grenoble, 17 rue des martyrs, 38054 Grenoble, France
}

Keywords:

Nafion ${ }^{\circledR}$

Hygrothermal aging

Fuel cell

Membrane degradation

Rejuvenation

\section{A B S T R A C T}

Nafion ${ }^{\circledR}$ membranes stored for long periods at $80{ }^{\circ} \mathrm{C}$ under elevated relative humidity up to $95 \% \mathrm{RH}$ exhibit large modifications of their properties attributed to the sulfonic acid end-group condensation into sulfonic anhydrides. The present study is devoted to the membrane property rejuvenation, namely the hydrolysis of the sulfonic anhydrides under different experimental conditions. Aged membranes were exposed to pure water and to acid solutions or vapors in order to check the reversibility of the condensation reaction. Indeed, the hydrolysis process is slow in pure water and limited while it is fast and complete in the presence of acid or base. The native polymer chemical structure and the main membrane properties (mechanical properties, hydrophilicity, etc.) are completely restored. No evidence of hygrothermal aging was observed after fuel cell operation and it is shown that a membrane previously aged under ex situ conditions can be completely rejuvenated when operated in fuel cell.

\section{Introduction}

Proton Exchange Membrane Fuel Cells (PEMFC) are an expanding area of research for environmentally friendly energy sources [1]. However, many problems need to be solved before large scale commercialization. One critical issue for PEMFC development is the membrane durability $[2,3]$. In order to understand the behavior of the membrane in-use and thus to elucidate the aging mechanism, ex situ tests are usually performed in the presence of $\mathrm{H}_{2} \mathrm{O}_{2}$ (Fenton reactive) [4]. It is commonly accepted that the main factor of chemical degradation during fuel cell operation is a radical attack inducing polymer chain scissions and consequently the loss of the mechanical properties and the membrane failure [5]. More recently, it has been shown that Nafion ${ }^{\circledR}$ membranes stored for long periods at elevated temperatures $\left(80^{\circ} \mathrm{C}\right)$ and humidity are subject to a hygrothermal aging modifying significantly the membranes properties (ion-exchange capacity, water sorption capability, ionic conductivity, mechanical properties, etc.) [6,7]. Infrared spectra of aged membranes revealed a new absorption band attributed to the formation of sulfonic anhydrides through a condensation reaction of the sulfonic acid end-groups [6,8]. This reaction was shown to be accelerated by larger membrane water contents but it did not occur when the membrane is immersed in liquid water or exposed

\footnotetext{
* Corresponding author. Tel.: +33 43878830 46; fax: +33 4387885097 E-mail address: gerard.gebel@cea.fr (G. Gebel).
}

to $100 \%$ relative humidity. The condensation reaction mechanism involves water molecules, sufficient pendant side chain mobility and an optimum distance between ionic groups. These conditions are favored increasing the membrane water content. Nevertheless, at very large water contents (typically when the membrane is immersed in liquid water) the condensation reaction is hindered either because of a less favorable morphology or an excess of water swaps the reaction from condensation to hydrolysis.

The present work is devoted to the study of the experimental conditions that can favor the hydrolysis reaction. The evolution of the membrane structure and properties will be studied for samples equilibrated in different media from pure water to acidic and alkaline solutions.

Membrane-electrode assemblies (MEAs) aged in fuel cells under different operating conditions will be analyzed to look for any sign of hydrothermal aging. Finally, a Nafion ${ }^{\circledR} 212$ membrane hygrothermally aged in ex situ conditions will be operated in a fuel cell and the membrane will be fully rejuvenated.

\section{Experimental}

\subsection{Materials and aging conditions}

Commercial perfluorinated sulfonic acid ion-exchange Nafion ${ }^{\circledR}$ 112 and 212 -CS membrane with 1100 gequiv $^{-1}$ as equivalent weight (EW) and a thickness of $50 \mu \mathrm{m}$ were provided by Du Pont de Nemours and Co. Nafion ${ }^{\circledR} 112$ membranes are prepared by 
extrusion of the Nafion ${ }^{\circledR}$ precursor $\left(\mathrm{SO}_{2} \mathrm{~F}\right.$ form $)$ while Nafion ${ }^{\circledR} 212$ CS membranes are prepared by solution casting and chemically stabilized (absence of carboxylic acid groups at the end of the polymer chains). As-received membranes were aged at $80^{\circ} \mathrm{C}$ in a climatic chamber at $0 \%, 80 \%$ or $95 \%$ of relative humidity $(\mathrm{RH})$. In previous studies [6,7], it was shown that the hygrothermal aging effects on the membrane properties is a function of aging time until a plateau is reached after at least a hundred of days. The degradation kinetics depends on the nature of the membrane (112 or 212) and the hygrothermal conditions ( $\mathrm{T}$ and $\mathrm{RH}$ ). However, the membrane structure, the swelling, conducting and mechanical properties are identical when the plateau is reached. In this work, the experiments were exclusively conducted on samples aged until the absence of evolution of the properties (the aging time and experimental conditions will be indicated for the reader information but all the studied samples can be considered as presenting similar properties). Rejuvenation tests were performed according to three different procedures:

- Immersion of an aged sample in pure water at $80^{\circ} \mathrm{C}$.

- Immersion of an aged sample in an aqueous solution of hydrochloric acid $(0.1 \mathrm{M})$ or sodium hydroxide $(0.1 \mathrm{M})$ at room temperature.

- Exposure of an aged sample to an acid saturated vapor. The samples were hung in an autoclave over a $1 \mathrm{M}$ hydrochloric acid solution and the temperature was raised at $80^{\circ} \mathrm{C}$.

\subsection{Tensile measurements}

Tensile tests were performed using an Instron dynamometer 4301 , at $23^{\circ} \mathrm{C}, 50 \% \mathrm{RH}$ equipped with specific roller grips specially adapted for thin films. H4 samples (dumbbell form samples with a straight section: $2 \mathrm{~mm} \times 13 \mathrm{~mm}$ ) were die-cut, on a PMMA slab (polymethyl methacrylate, in order to prevent any default). The samples were cut along the length roll direction and equilibrated at $23^{\circ} \mathrm{C}, 50 \% \mathrm{RH}$ for $24 \mathrm{~h}$. The measurements were conducted in the same conditions. 8 samples were analyzed with a cross head speed of $2.5 \mathrm{~mm} \mathrm{~min}^{-1}$.

\subsection{Dynamic vapor sorption (DVS)}

DVS is a well-established method to record sorption isotherms. The DVS-1000-Org instrument, supplied by Surface Measurement Systems (SMS, London, UK), is based on an ultrasensitive Cahn recording microbalance with a mass resolution of $\pm 0.1 \mu \mathrm{g}$. Sorption isotherms were recorded at $50^{\circ} \mathrm{C}$ between activities 0 and 0.9 , incremented by step of 0.1 (the water activity corresponds to the ratio of water partial pressure $(p)$ and of saturated pressure (po)). The temperature is maintained constant $\left( \pm 0.1^{\circ} \mathrm{C}\right)$ as the system is located in a temperature-controlled incubator. Samples of $20-40 \mu \mathrm{g}$ are loaded in the pan and $3 \mathrm{~h}$ are necessary to reach the equilibrium at each step.

\subsection{Infrared spectroscopy}

Samples were equilibrated for $24 \mathrm{~h}$ at $23^{\circ} \mathrm{C}$ and 50\%RH (controlled conditions of the room where the samples are equilibrated). FTIR spectra were collected on a Bruker IFS-28 FT-IR spectrometer using transmission mode. Each spectrum resulting from 32 scans was recorded from 4000 to $400 \mathrm{~cm}^{-1}$ at $25^{\circ} \mathrm{C}$, with a spectral resolution of $4 \mathrm{~cm}^{-1}$. Air was employed as background reference for all measurements.

Quantitative information cannot be obtained in the absence of an internal reference band. However, the relative intensity of some specific IR bands can be compared from one spectrum to another since the same membrane is analyzed under similar experimental protocols (when the lines are not saturated in the region of interest).

\subsection{Nuclear magnetic resonance}

Solid state NMR experiments were performed on a Bruker DSX400 in a $2.5 \mathrm{~mm} \mathrm{H} / \mathrm{F}-\mathrm{X}$ probe. Magic angle spinning (MAS) spectra of ${ }^{1} \mathrm{H}$ and ${ }^{19} \mathrm{~F}$ were acquired at $400.15 \mathrm{MHz}$ and $376.49 \mathrm{MHz}$ respectively. Small pieces of Nafion ${ }^{\circledR}$ membranes were packed into $2.5 \mathrm{~mm}$ rotors and spun at $30 \mathrm{kHz}$. Each spectrum was the average of 16 scans for ${ }^{1} \mathrm{H}$ and 64 scans for ${ }^{19} \mathrm{~F}$. $\pi / 2$ pulses of $3 \mu$ s were used for both nuclei. TMS (tetramethylsilane) and $\mathrm{NaF}(-221 \mathrm{ppm})$ were used as external references for ${ }^{1} \mathrm{H}$ and ${ }^{19} \mathrm{~F}$ respectively.

\subsection{Membrane aging and rejuvenation in fuel cell conditions}

A as-received Nafion ${ }^{\circledR}$ NRE212 membrane was hot pressed at $135^{\circ} \mathrm{C}$ between two commercial electrodes E-LAT LT 140E-W/SI from BASF applying a stress of $10 \mathrm{MPa}$ during 3 and a half minutes to build $25 \mathrm{~cm}^{2}$ geometric active area membrane electrode assembly (MEA). The Pt loading of the electrodes is about $0.5 \mathrm{mg} \mathrm{cm}^{-2}$.

MEAs were aged in fuel cells under different experimental conditions from 200 to $1900 \mathrm{~h}$ at temperatures varying from 60 to $80^{\circ} \mathrm{C}$ and current densities from 0.2 to $1 \mathrm{Acm}^{-2}$, either in static or dynamic current load.

In order to carry out fuel cell tests, an ex situ aged membrane at $80^{\circ} \mathrm{C}$ and $95 \% \mathrm{RH}$ during 258 days has been stacked between two commercial E-LAT electrodes into a $25 \mathrm{~cm}^{2}$ single cell test fixture without any hot-pressing in order to get rid of the impact of the hot-pressing process. This MEA was tested at $60^{\circ} \mathrm{C}$ with dry and pure $\mathrm{H}_{2}$ at the anode side and either fully humidified pure $\mathrm{O}_{2}$ or air at the cathode side at 1.5 absolute bars in co-flow configuration. The gas stoichiometries were $1.2,1.5$ and 2 for $\mathrm{H}_{2}, \mathrm{O}_{2}$ and air, respectively. The minimum values for gas flow were respectively 20,10 and $70 \mathrm{Nml} \mathrm{min}^{-1}$ for $\mathrm{H}_{2}, \mathrm{O}_{2}$ and air. This corresponds, with the given stoichiometries, to current densities of $100 \mathrm{~mA} \mathrm{~cm}^{-2}$ for $\mathrm{H}_{2}$ and $\mathrm{O}_{2}$ and $75 \mathrm{mAcm}^{-2}$ for air. That means that for a current density bellow these limits, gas flow was fixed to the minimum value for the corresponding reactant. During the test, the current was kept constant and the cell voltage was recorded.

Electrochemical impedance spectroscopy (EIS) measurements from $40 \mathrm{kHz}$ to $0.1 \mathrm{~Hz}$ with 6 points per decade were conducted in galvanodynamic mode in order to follow the dynamic electrochemical response of the fuel cell.

\section{Results and discussion}

\subsection{Hydrolysis of ex situ hygrothermally aged Nafion ${ }^{\circledR}$}

\subsubsection{IR spectroscopy analysis}

A Nafion ${ }^{\circledR} 112$ membrane aged at $80^{\circ} \mathrm{C}$ and $80 \% \mathrm{RH}$ during 393 days was immersed in pure water at $80^{\circ} \mathrm{C}$ for different periods. Infrared spectroscopy was used to follow the hydrolysis reaction as a function of the immersion time focusing on the $1300-1600 \mathrm{~cm}^{-1}$ region of the spectra (Fig. 1).

The absorption band attributed to the anhydride groups $[6,8]$ at $1440 \mathrm{~cm}^{-1}$ decreases upon aging especially during the first 10 days. For longer aging times, the structure seems to stabilize with a loss of $50 \%$ of the anhydride peak intensity after 234 days of immersion. This result reveals that the hydrolysis reaction in pure water is slow and equilibrated. It follows that the previous measurements [6,7] of the membrane water uptake and ionic conductivity are not affected by the membrane immersion in liquid water since the experiment duration was very short relative to the hydrolysis kinetic especially for experiments performed at room temperature. 


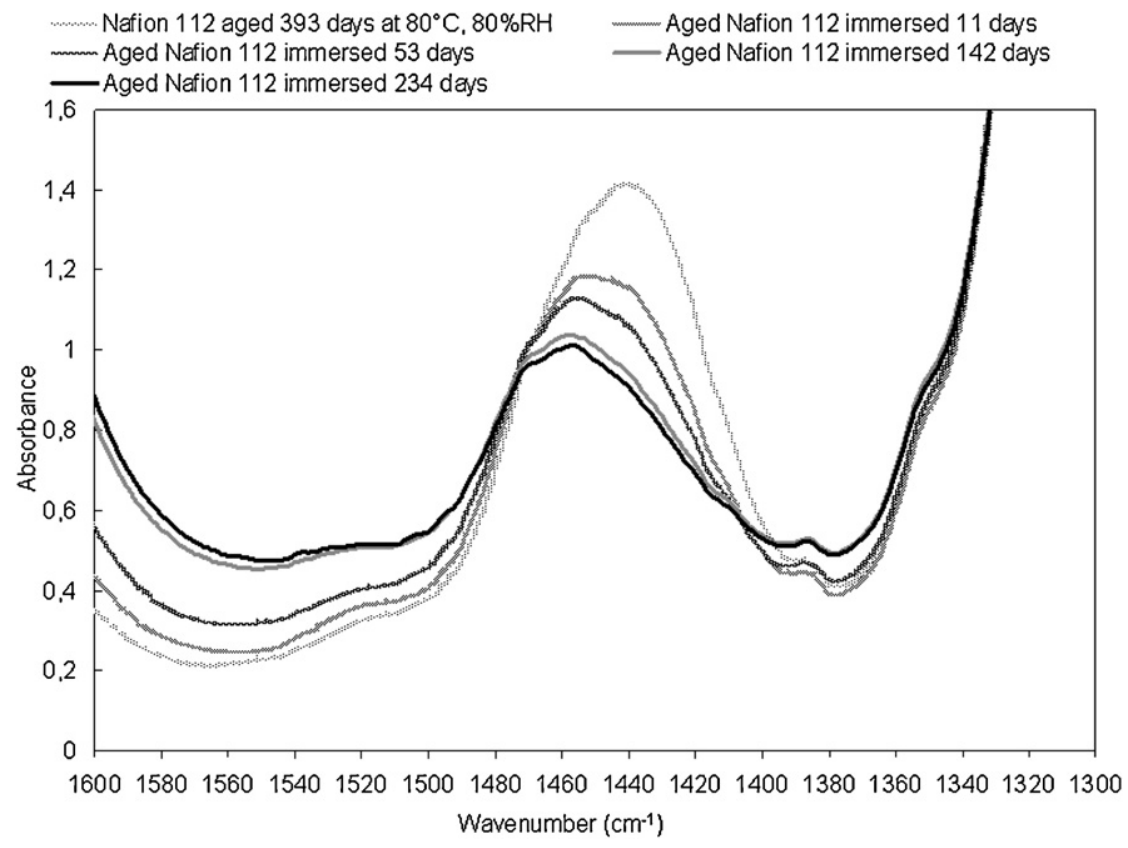

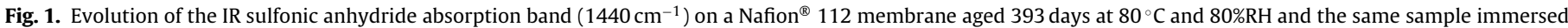
in pure water at $80^{\circ} \mathrm{C}$ for various durations.

A sample of Nafion ${ }^{\circledR} 212$-CS samples previously aged in a climatic chamber 230 days at $80^{\circ} \mathrm{C}$ was immersed in a hydrochloric acid solution and then studied by infrared spectroscopy (Fig. 2). After immersion, it has been observed that the IR absorption band at $1440 \mathrm{~cm}^{-1}$ corresponding to the sulfonic anhydride [8] has completely disappeared. Simultaneously, the intensity of the absorption bands corresponding to water $\left(1620 \mathrm{~cm}^{-1}\right)$, oxonium $\left(1710 \mathrm{~cm}^{-1}\right)$ and hydrogen bonds $\left(3000-4000 \mathrm{~cm}^{-1}\right)$ increased significantly. The IR spectrum of Nafion ${ }^{\circledR}$ sample aged and then immersed in acid solution is overlaid to the one of pristine Nafion ${ }^{\circledR}$ (Fig. 2). It can be concluded that the sulfonic anhydrides are completely hydrolyzed by the catalytic action of the strong acid in liquid water.

When immersed in liquid acidic solutions, there is a combined effect of water and acidic species that favors the hydrolysis reaction. The condensation reaction does not occur in pure liquid water and a partial hydrolysis is observed for previously aged samples. Therefore, it is of interest to study the hydrolysis reaction in acidic vapors. In the presence of water vapor with a relative humidity lower than $100 \%$, the reaction is shifted towards condensation while, in the presence of acids, it is shifted towards hydrolysis. A Nafion ${ }^{\circledR} 212-$ CS sample, previously aged 515 days in a climatic chamber at $80^{\circ} \mathrm{C}$ under a partially humidified atmosphere $(80 \% \mathrm{RH})$ was exposed to saturated vapor obtained from a hydrochloric acid solution ( $1 \mathrm{M})$, at $80^{\circ} \mathrm{C}$. After 32 days in acid vapor (Fig. 3), it is observed that the anhydride peak has disappeared. This suggests that the sulfonic anhydride was hydrolyzed by the catalytic action of the strong acid in vapor phase.

Another sample previously aged 355 days at $80^{\circ} \mathrm{C}$ and $80 \% \mathrm{RH}$ was immersed in acidic solutions at various concentrations. The results indicate that the hydrolysis is a very fast process in concentrated acidic solutions since the anhydride signature disappears

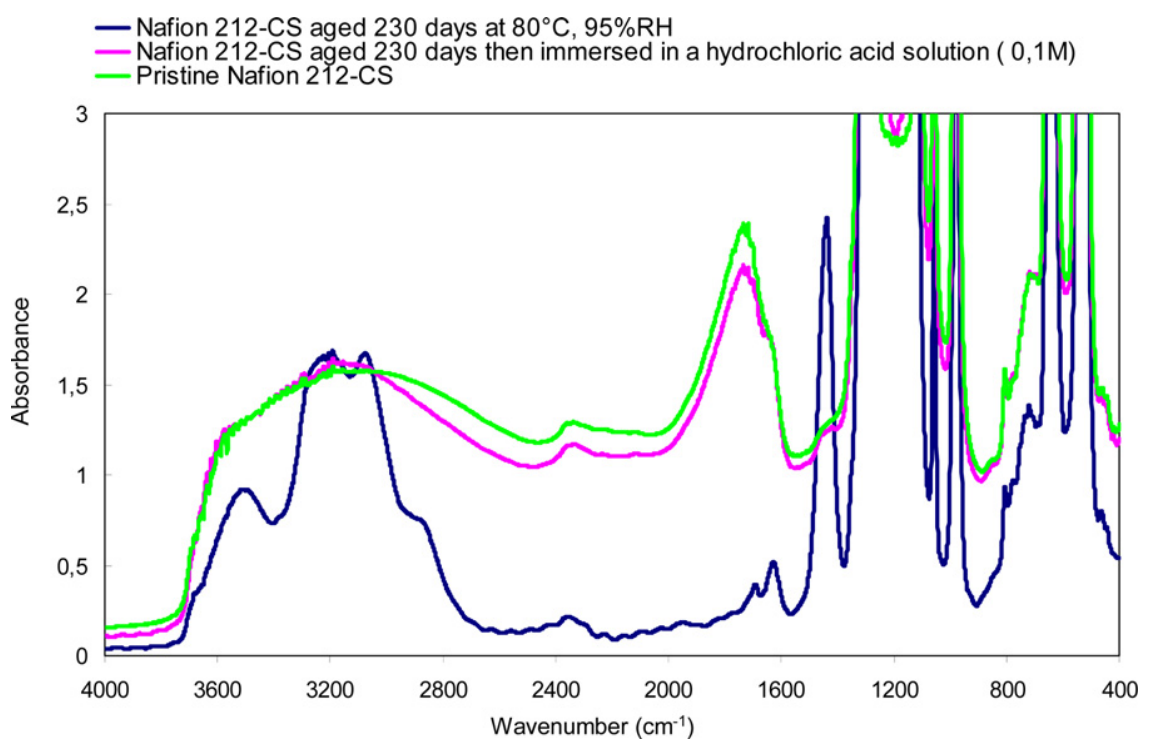

Fig. 2. IR spectra of pristine Nafion ${ }^{\circledR} 212-\mathrm{CS}$, Nafion ${ }^{\circledR} 212-\mathrm{CS}$ membrane aged 230 days at $80{ }^{\circ} \mathrm{C}$ and $95 \% \mathrm{RH}$ and the same sample hydrolyzed in $\mathrm{HCl}$ solution $0.1 \mathrm{M}$. 


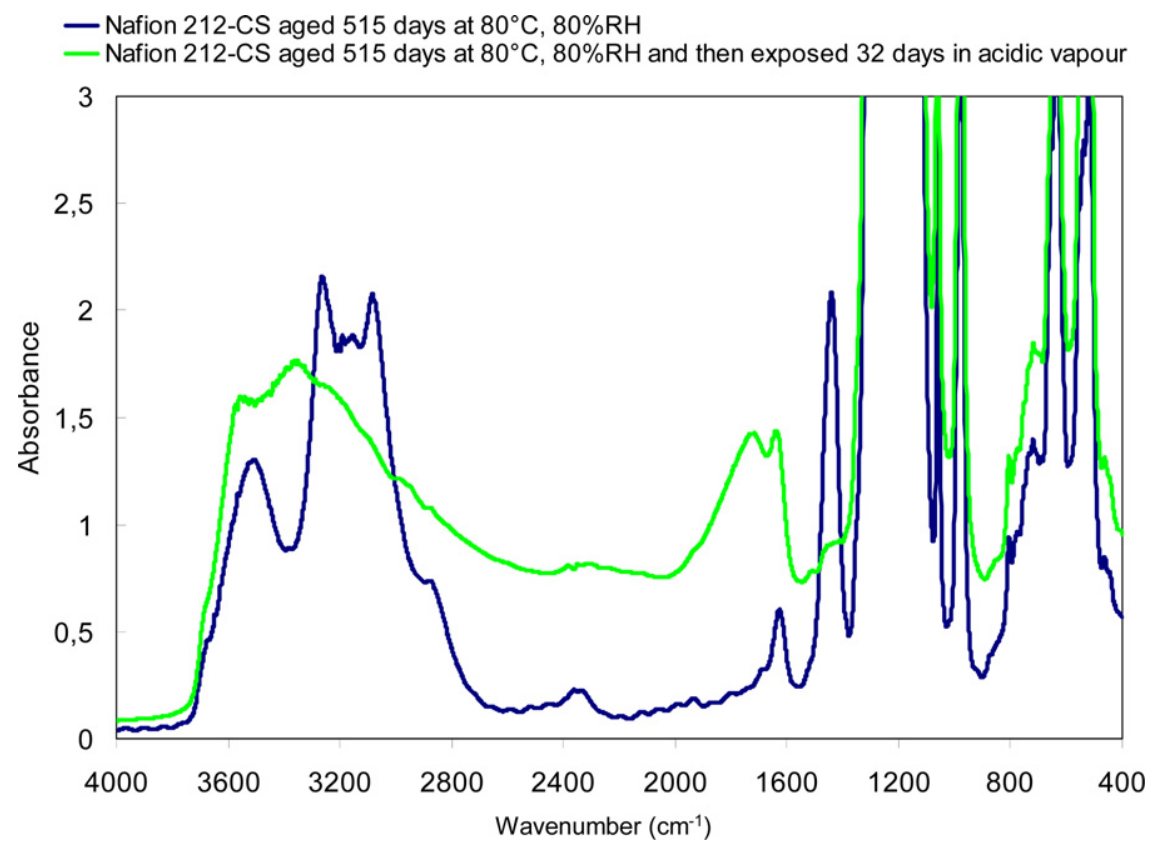

Fig. 3. IR spectra of Nafion ${ }^{\circledR} 212-\mathrm{CS}$ membrane aged 515 days at $80^{\circ} \mathrm{C}$ and $\mathrm{RH}=80 \%$ and the same sample exposed 32 days to acid atmosphere at $80{ }^{\circ} \mathrm{C}$.

within few minutes. As expected, the reaction significantly appears slower when the $\mathrm{HCl}$ concentration is lowered to $10^{-3} \mathrm{M}$. More than $20 \mathrm{~h}$ are then necessary to observe the vanishing of the $1440 \mathrm{~cm}^{-1}$ IR band (Fig. 4). For low acid concentration solutions, the chemical structure recovery is not complete, as previously observed for a membrane treatment in pure water. In order to completely shift the reaction towards hydrolysis, it is recommended to use an acidic concentration higher than $10^{-3} \mathrm{M}$. Nafion ${ }^{\circledR}$ membranes are usually pretreated at elevated temperatures in concentrated acidic solutions before use in order to avoid any effect of the hydrothermal history and any possible pollution by metallic cations. The present work also reveal that it will also suppress any effect of hydrothermal aging that can occur for samples stored over long periods.
An additional experiment was conducted using a concentrated acetic acid solution $\left(1.3 \mathrm{~mol} \mathrm{~L}^{-1}\right)$. The sulfonic anhydride hydrolysis is also observed in the presence of weak acids indicating that the hydrolysis reaction is catalyzed by the excess of protons whatever the strength of the acid.

Since significant differences were observed in the anhydride hydrolysis kinetics between acidic solutions and pure water, the effect of membrane immersion in a base was then investigated. A sample of Nafion ${ }^{\circledR} 212$, previously aged in a climatic chamber at $80^{\circ} \mathrm{C}, 95 \% \mathrm{RH}$ during 245 days, was immersed for $4 \mathrm{~min}$ in a sodium hydroxide solution $0.1 \mathrm{M}$. As observed in the presence of hydrochloric acid, the infrared absorption band at $1440 \mathrm{~cm}^{-1}$ disappears in the presence of sodium hydroxide while the water absorption band intensity $\left(1620 \mathrm{~cm}^{-1}\right)$ increases. The IR spectrum of the $\mathrm{NaOH}$

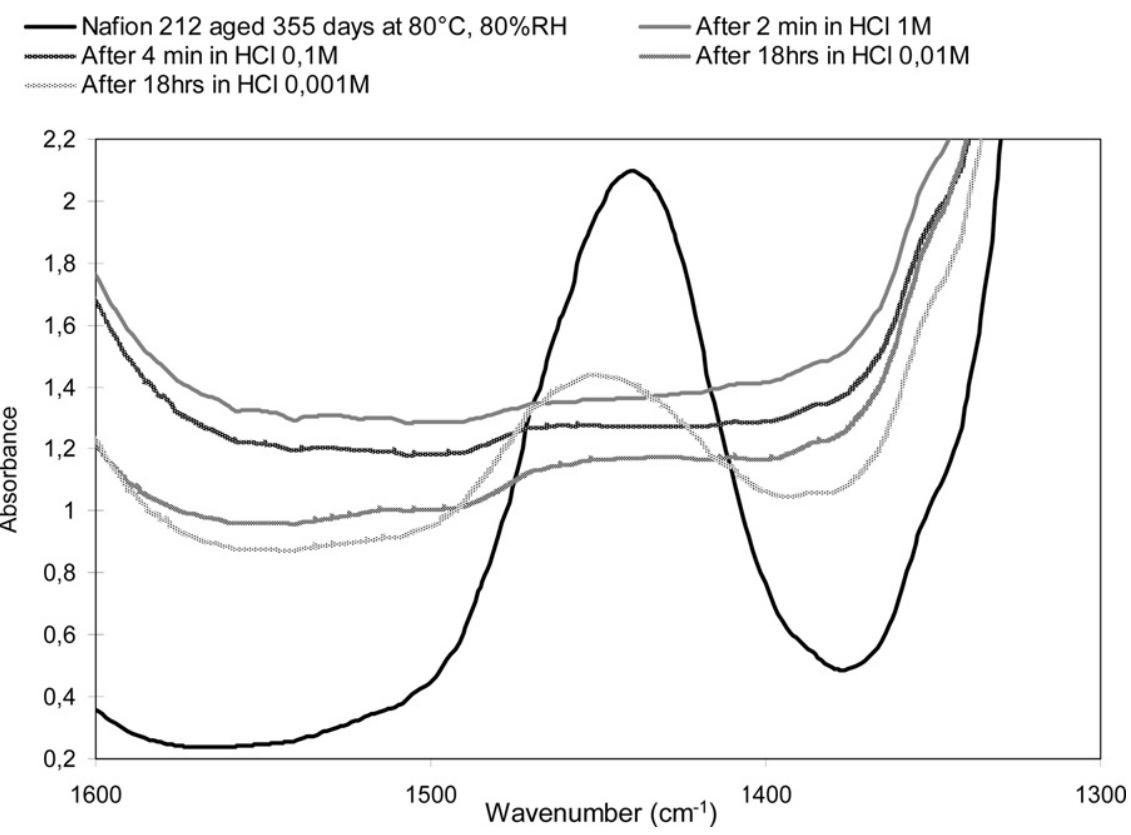

Fig. 4. IR spectra of Nafion ${ }^{\circledR} 212-\mathrm{CS}$ aged 355 days at $80^{\circ} \mathrm{C}$ and $\mathrm{RH}=80 \%$ then hydrolysed in chlorhydric acid solutions for various concentrations and durations. 


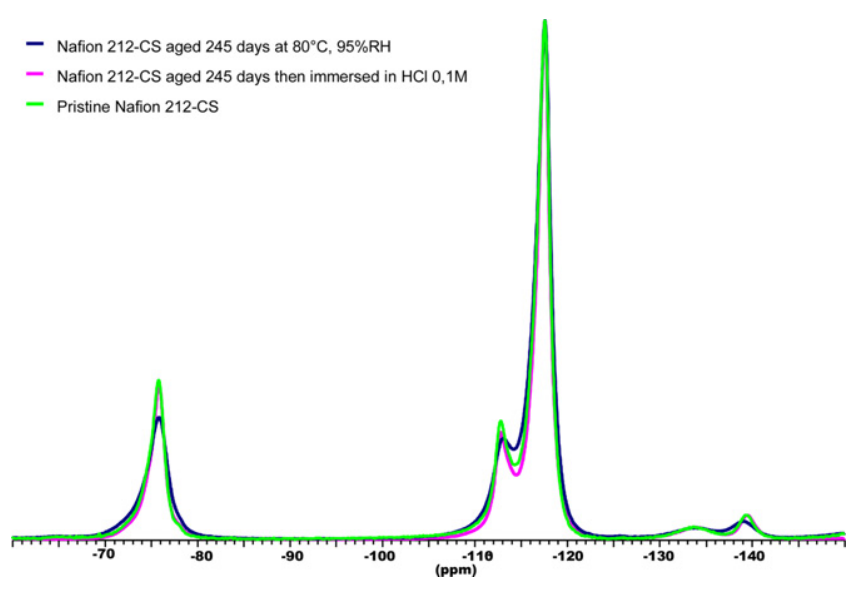

Fig. 5. ${ }^{19} \mathrm{~F}$ NMR spectra of pristine Nafion ${ }^{\circledR} 212-\mathrm{CS}$ (green spectrum), of Nafion ${ }^{\circledR}$ 212-CS aged 245 days at $80^{\circ} \mathrm{C}$ and $\mathrm{RH}=95 \%$ (blue spectrum) and the same sample hydrolysed by $\mathrm{HCl} 0.1 \mathrm{M}$ (pink spectrum). (For interpretation of the references to color in this figure legend, the reader is referred to the web version of the article.)

hydrolyzed aged Nafion ${ }^{\circledR}$ is similar to the one of non-aged $\mathrm{Na}^{+}$ Nafion ${ }^{\circledR}$ indicating that the membranes are also rejuvenated.

\subsubsection{NMR analysis}

The effect of the hygrothermal aging on the ${ }^{19} \mathrm{~F} \mathrm{NMR}$ spectra was shown to be mainly restricted to an enlargement of the NMR line at -112 ppm corresponding to the fluorine group of the pendant side-chains neighboring the sulfonic acid group. It was attributed to a restricted mobility of the pendant chain consecutive to the crosslinking of the sulfonic groups to form anhydrides. The hydrolysis in acidic solution $(0.1 \mathrm{M} \mathrm{HCl})$ restores the sulfonic groups and consequently the mobility of the fluorine group. The ${ }^{19} \mathrm{~F}$ NMR spectra are then very similar for the hydrolyzed aged membrane and the pristine Nafion ${ }^{\circledR}$ (Fig. 5).

The analysis in ${ }^{1} \mathrm{H}$ NMR reveals that the hydrolysed Nafion ${ }^{\circledR}$ spectrum contains only one component, as observed for pristine Nafion ${ }^{\circledR}$ (Fig. 6). The second peak, which appears after the anhydride formation [6,7] for long aging times and which represents a degradation tracer, has completely disappeared.

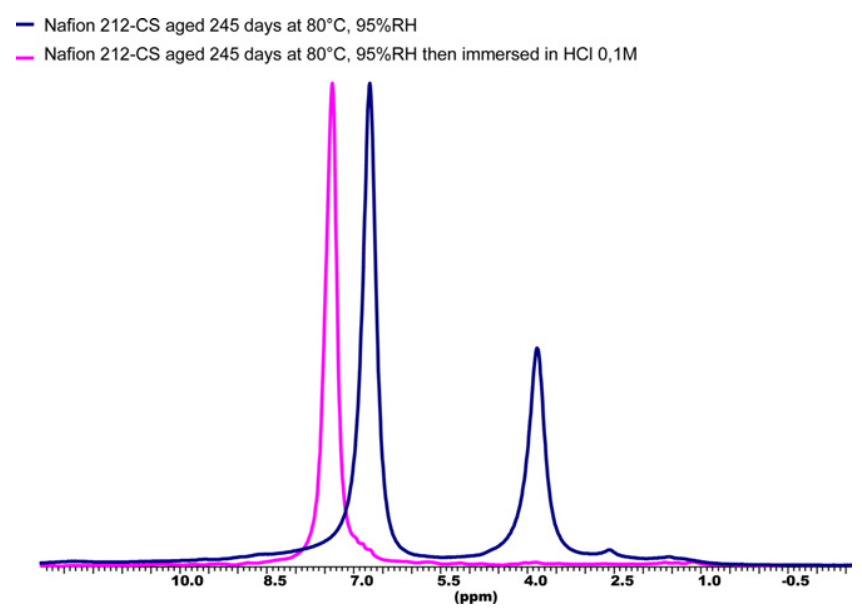

Fig. 6. ${ }^{1} \mathrm{H}$ NMR spectra of Nafion ${ }^{\circledR} 212-\mathrm{CS}$ aged 245 days at $80^{\circ} \mathrm{C}$ and $\mathrm{RH}=95 \%$ (blue spectrum) and the same sample hydrolysed by $\mathrm{HCl} 0.1 \mathrm{M}$ (pink spectrum). (For interpretation of the references to color in this figure legend, the reader is referred to the web version of the article.)

A proton NMR analysis was also conducted on aged Nafion ${ }^{\circledR}$ membranes immersed for $4 \mathrm{~min}$ in $0.1 \mathrm{M} \mathrm{NaOH}$ solution. The $1 \mathrm{H}$ NMR spectrum of the $\mathrm{NaOH}$ hydrolyzed aged Nafion ${ }^{\circledR}$ exhibits only a single peak containing spectrum as observed for $\mathrm{HCl}$ hydrolyzed membranes (Fig. 6) but this peak appears shifted due to the $\mathrm{Na}^{+}$ neutralization (the NMR chemical shift of water within the membrane depends on the membrane water content and the nature of the counterion).

\subsubsection{Mechanical and swelling properties}

In addition to a modification of the IR and NMR spectra attributed to the formation of sulfonic anhydrides, previous studies have evidenced significant modifications of the swelling, conducting and mechanical properties [6,7]. IR and NMR data suggest a complete rejuvenation of the chemical structure and it is therefore of interest to check the effect of hydrolysis on the main membrane properties to evaluate the occurrence of a partial or a complete rejuvenation. Hydrolysed Nafion ${ }^{\circledR}$ mechanical properties (Fig. 7) and

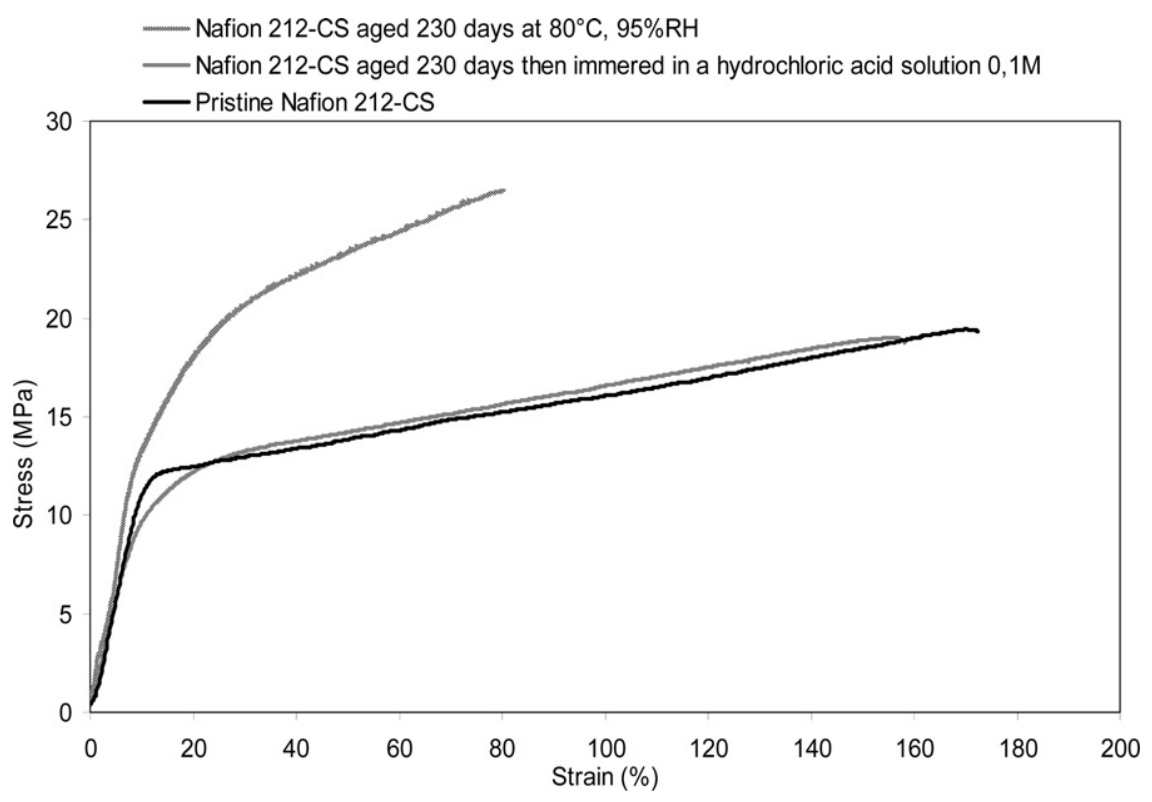

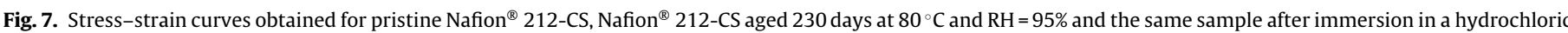
acid solution $0.1 \mathrm{M}$. 


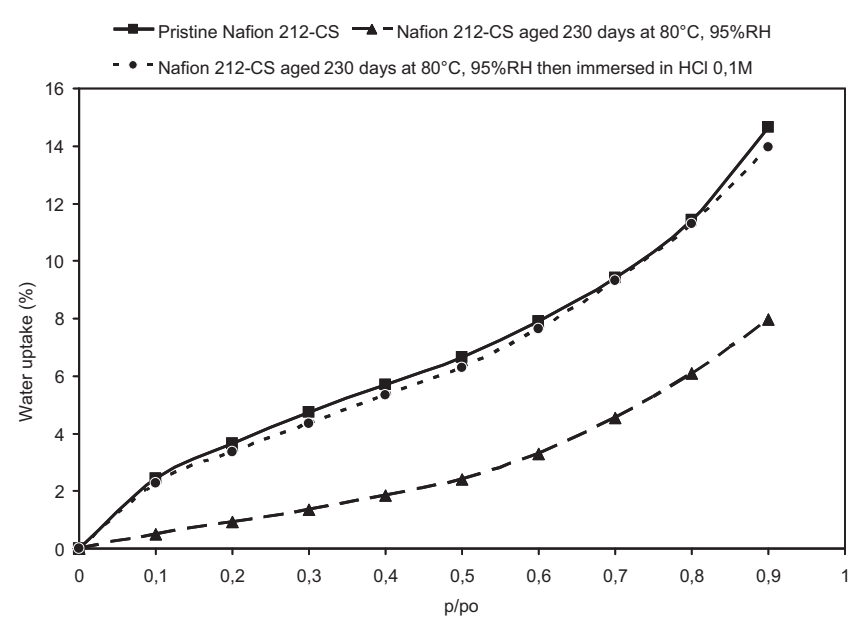

Fig. 8. Water sorption isotherms obtained for pristine Nafion ${ }^{\circledR} 212-\mathrm{CS}$, Nafion ${ }^{\circledR} 212$ CS aged 230 days at $80^{\circ} \mathrm{C}$ and $\mathrm{RH}=95 \%$ and the same sample after immersion in a hydrochloric acid solution $0.1 \mathrm{M}$.

hydrophilicity (Fig. 8) were measured before and after hydrolysis in $0.1 \mathrm{M}$ acidic solution.

The mechanical properties appeared completely recovered in terms of Young modulus and elongation at break when compared to the same data obtained with unaged Nafion ${ }^{\circledR}$. The slight differences between the two curves are mainly due to the fact that the rejuvenated membrane has undergone a hygrothermal treatment at elevated temperature inducing slight changes in the mechanical properties. Similarly, the water sorption isotherm of the hydrolyzed Nafion ${ }^{\circledR}$ membrane appears identical to the pristine membrane one revealing a complete rejuvenation of the membrane properties.

\subsection{Hygrothermal degradation and fuel cells test}

\subsubsection{Hygrothermal degradation in fuel cell conditions}

In situ aged MEA membranes were analyzed by infrared and NMR spectroscopy and mechanical testing after removal of the electrodes by immersion in a 1:1 water ethanol solution at ambient temperature and then rinsing three times in pure water. The analyses were conducted on different location of the MEA close to the gas inlet and outlet, in front of the ribs of the bipolar plate used for current collection or in front of the gas distribution channels. None of these experiments revealed any degradation that could be attributed to hydrothermal aging and especially the $1440 \mathrm{~cm}^{-1}$ absorption band was not observed in infrared spectra. This absence of hygrothermal degradation is not due to the hydroalcoholic treatment conducted at room temperature since it has been checked that such treatment has no significant effect on ex situ aged membranes. The fuel cell was operated up to almost $2000 \mathrm{~h}$ which should have been sufficient to detect a significant effect on the infrared spectra according to the previous ex situ experiments [6,7].

An experiment in fuel cell was conducted applying an on-off cycling test at $80^{\circ} \mathrm{C}$ during several hundreds of hours in order to generate hydric cycles with successive membrane swelling and shrinking. Such aging tests are known to induce significant physical degradations compared to the aging tests performed under stationary conditions. At the end of the test, no degradation that could be attributed to a hygrothermal aging was observed. A membrane was then mounted in a fuel cell with only gas diffusion layers and hydric cycles under inert atmosphere (nitrogen) were applied for several hundreds of hours. This experiment revealed a significant hydrothermal aging with the presence of the $1440 \mathrm{~cm}^{-1}$ absorption band in the infrared spectrum as observed in previous ex situ aging experiments. This result reveals that the hygrothermal aging occurs

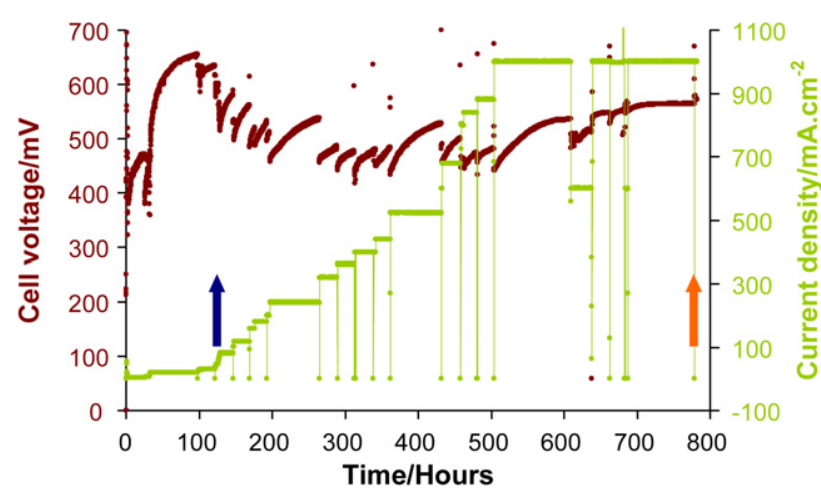

Fig. 9. Evolution of cell voltage and current density during fuel cell operation obtain with a MEA made with an ex situ aged Nafion ${ }^{\circledR} 212-\mathrm{CS}$ membrane at $80^{\circ} \mathrm{C}$ and $\mathrm{RH}=95 \%$ during 258 days. $60^{\circ} \mathrm{C}, 1.5$ absolute bars, dry $\mathrm{H}_{2}$ at the anode, fully humidified reactant at the cathode: $\mathrm{O}_{2}$ except from 600 to $640 \mathrm{~h}$ and above $805 \mathrm{~h}$ where air has been used. The blue and orange arrows pointed out when the initial and final EIS measurements at $20 \mathrm{~mA} \mathrm{~cm}^{-2}$ with $\mathrm{O}_{2}$ have been conducted. (For interpretation of the references to color in this figure legend, the reader is referred to the web version of the article.)

for a membrane mounted in a fuel cell and consequently that the hydrothermal aging is hindered by the fuel cell operation whatever the operating conditions. This test also reveals that the aging time was sufficient to observe the degradation process if it had occurred during fuel cell operation. In addition, it confirms that the ex situ hygrothermal aging is not consecutive to air pollution during the long storage in the climatic chamber since similar aging effect was observed in this test performed under nitrogen atmosphere.

\subsubsection{Membrane rejuvenation in fuel cells}

Very poor fuel cell performance was obtained at the beginning of the fuel cell test with an ex situ aged Nafion ${ }^{\circledR} 212$ membrane at $80^{\circ} \mathrm{C}$ and $95 \% \mathrm{RH}$ during 258 days (Fig. 9). More precisely, the cell voltage was only $320 \mathrm{mV}$ with pure $\mathrm{O}_{2}$ at the cathode side and for a current density as low as $3 \mathrm{~mA} \mathrm{~cm}^{-2}$. Despite a much lower membrane gas permeability for aged membranes compared to a fresh 212-CS membrane, quite low values of open circuit voltage $(\mathrm{OCV})$ were obtained, namely around $700 \mathrm{mV}$. Therefore, the low OCV value is not related to the gas crossover as usually concluded but it could be ascribed excessive ohmic drops in the MEA due to the combined effect of a very low membrane proton conductivity, electrode hydration issues and a poor membrane/electrode interface. Indeed, the internal resistance of the test bench is very small compared to the highly resistive MEA. It follows that the current density used for OCV determination is thus non-negligible and induces a significant decrease of cell potential. After 1 day of operation at $3 \mathrm{~mA} \mathrm{~cm}^{-2}$, the cell voltage increased from almost $0 \mathrm{~V}$ to $472 \mathrm{mV}$. The current density was then progressively increased step by step keeping the cell voltage in the range of $500 \mathrm{mV}( \pm 100 \mathrm{mV})$ in order to produce as much water as possible to favor membrane and electrode hydration. It has been possible to reach $1 \mathrm{~A} \mathrm{~cm}^{-2}$ after $500 \mathrm{~h}$. After $610 \mathrm{~h}$ of operation, the cathode reactant was switched from $\mathrm{O}_{2}$ to air during $30 \mathrm{~h}$ in order to check the effect of oxygen partial pressure on the cell performance. The current density was decreased down to $600 \mathrm{~mA} \mathrm{~cm}^{-2}$ so as to keep the cell voltage around $500 \mathrm{mV}$. An improvement of the cell performance was also observed in these conditions and the gas feed was switched back to oxygen until the performance reaches a steady state value. In the absence of cell voltage evolution at $1 \mathrm{~A} \mathrm{~cm}^{-2}$ during $100 \mathrm{~h}$, we have considered that the rejuvenation was complete and stopped the experiment.

During this fuel cell test, impedance spectra (EIS) were recorded occasionally at $20 \mathrm{~mA} \mathrm{~cm}^{-2}$ in $\mathrm{O}_{2}$ from 90 to $780 \mathrm{~h}$ of operation (Fig. 10). It appears clearly on the EIS spectra that the increase in performance originates mainly from a progressive reduction ohmic 


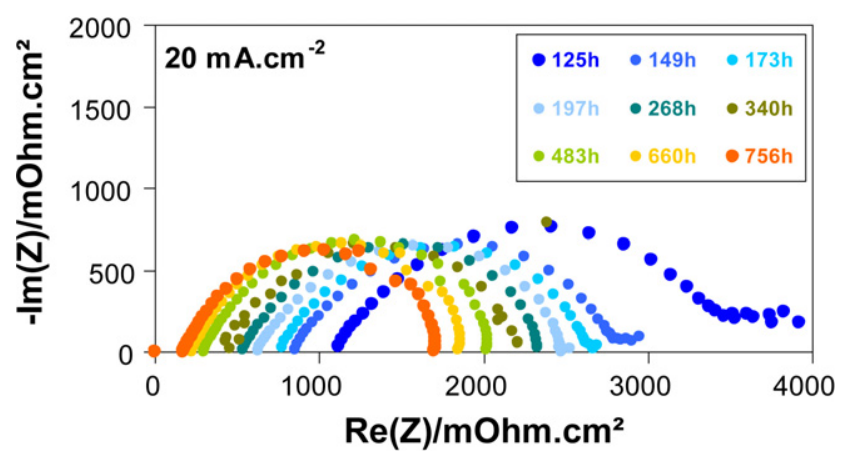

Fig. 10. Evolution of the electrochemical impedance spectra recorded at $20 \mathrm{~mA} \mathrm{~cm}^{-2}$ during fuel cell rejuvenation experiment of a Nafion ${ }^{\circledR} 212$-CS membrane aged ex situ during 258 days at $80^{\circ} \mathrm{C}$ and $\mathrm{RH}=95 \%$.

drops. Indeed, the high frequency resistance ascribed to the ionic membrane resistance decreases from 1115 to $173 \mathrm{~m} \Omega \mathrm{cm}^{2}$ (Fig. 11) and this decrease by a factor 6.5 which is very close to the effect of ex situ aging on the membrane proton conductivity suggesting a complete membrane rejuvenation [7]. In addition, the initial contribution at low frequency around a few tenths of $\mathrm{Hz}$ assigned to mass transport limitations vanished during the first 2 days of operation. A progressive decrease of the first semi-circle at a characteristic frequency of a few decades ascribed to charge transfer from 2500 to $1500 \mathrm{~m} \Omega \mathrm{cm}^{2}$ is also observed (Fig. 11). These two phenomena can be attributed to a progressive conditioning of the electrodes, namely a better hydration of the ionomer in the active layers which is necessary to reach the maximum electrochemical performance.

In order to confirm the membrane rejuvenation during fuel cell operation, in situ EIS measurements at different current densities, e.g. $40,80,180,320$ and $500 \mathrm{~mA} \mathrm{~cm}^{-2}$, were conducted in air at $60^{\circ} \mathrm{C}$ after complete recovery of the performance ( $800 \mathrm{~h}$ of operation). The spectra were compared to the data measured with a fresh Nafion ${ }^{\circledR}$ NRE212 and similar electrodes after a $24 \mathrm{~h}$ conditioning process (Fig. 12). The dynamic electrochemical response is very similar whatever the applied current density which confirmed the membrane rejuvenation. The slight differences are probably due to the effect of $800 \mathrm{~h}$ of operation on the membrane electrode interface and on the electrode aging.

This experiment clearly shows that the membrane degradation mechanism described previously as a condensation of sulfonic acid groups into anhydride [6,7] is reversible during a fuel cell test. It follows that the hygrothermal aging cannot occur during fuel cell operation as revealed by the absence of aging effects after fuel cell

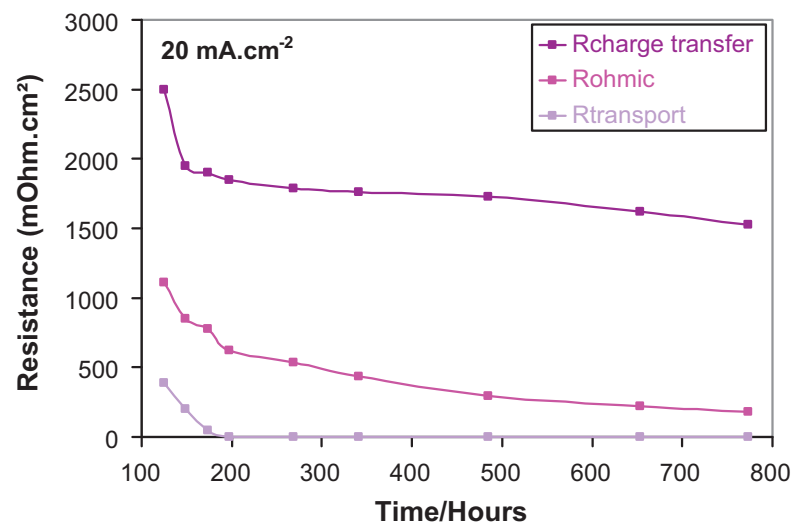

Fig. 11. Evolution of the resistances evaluated from EIS at $20 \mathrm{~mA} \mathrm{~cm}^{-2}$ coming from charge transfer, ohmic and transport limitations during fuel cell rejuvenation experiment of a Nafion ${ }^{\circledR} 212$-CS membrane aged ex situ during 258 days at $80^{\circ} \mathrm{C}$ and $\mathrm{RH}=95 \%$.
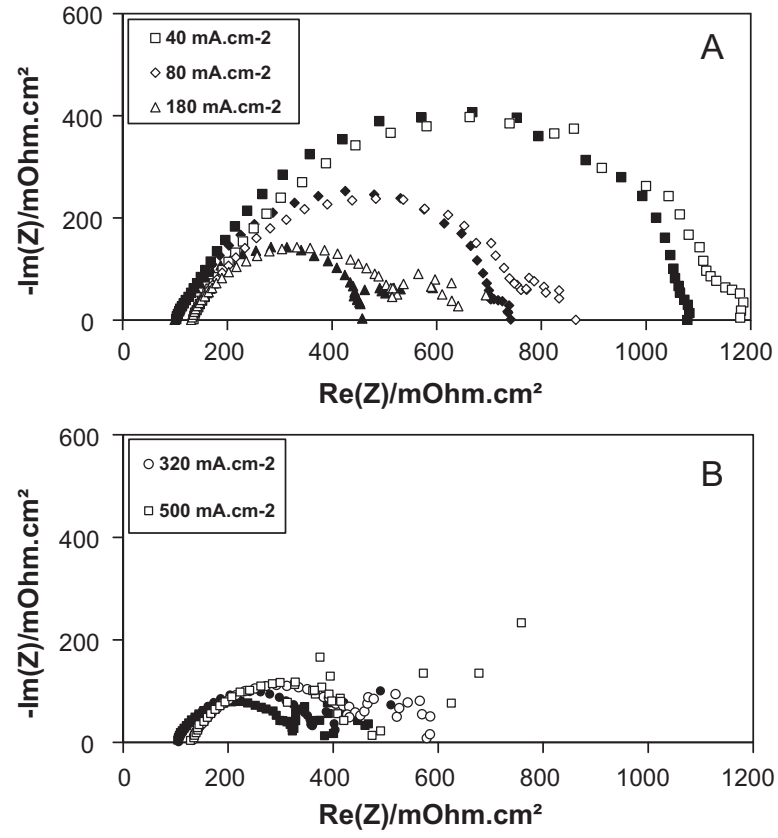

Fig. 12. Electrochemical impedance spectra obtained for MEAs made with a fresh hot pressed Nafion ${ }^{\circledR} 212-C S$ membrane (full symbol) and with a Nafion ${ }^{\circledR} 212$-CS membrane aged ex situ during 258 days at $80^{\circ} \mathrm{C}$ and $\mathrm{RH}=95 \%$ after $800 \mathrm{~h}$ of fuel cell operation (open symbol). (a) 40,80,180 $\mathrm{mA} \mathrm{cm}^{-2}$ and (b) 320 and $500 \mathrm{~mA} \mathrm{~cm}^{-2}$ $60{ }^{\circ} \mathrm{C}, 1.5$ absolute bars, dry $\mathrm{H}_{2}$ at the anode and fully humidified air at the cathode.

experiments performed with new membranes and by the fact that an aged membrane is fully rejuvenated under fuel cell operation.

\section{Conclusion}

The hygrothermal aging of Nafion ${ }^{\circledR}$ corresponds to the sulfonic acid condensation into sulfonic anhydrides. Surprisingly, this reaction appeared to be favored by the presence of water molecules in the vicinity of the acid groups but it is hindered in the presence of an excess of water (membrane equilibrated in liquid water or saturated vapor). In this work, it is shown that an aged membrane is partially hydrolyzed when immersed in pure water revealing that the condensation-hydrolysis reaction appears as an equilibrated reaction [9]. On the contrary, the reaction is shifted towards a complete hydrolysis of the anhydride groups in the presence of acid or base. In these conditions, the mechanical, swelling and conducting properties in addition to the chemical structure are recovered and appear similar to those of pristine Nafion ${ }^{\circledR}$. In that sense, aged Nafion ${ }^{\circledR}$ membranes can be considered as completely rejuvenated.

The analysis of membranes aged in fuel cells under various experimental conditions did not reveal any evidence of hygrothermal aging. In addition, an ex situ aged membrane appears completely rejuvenated after $800 \mathrm{~h}$ of fuel cell operation. These two results clearly indicate that the hygrothermal aging should not occur in fuel cells.

\section{Acknowledgments}

This work was supported by the French National Agency of Research (ANR PAN-H DVD AME). We thank C. Lorentz from IRCELYON for the help in the NMR experiments.

\section{References}

[1] Handbook of Fuel Cells: Fundamentals, Technology, Applications, John Wiley, 2004 
[2] R. Borup, J. Meyers, B. Pivovar, Y.S. Kim, R. Mukundan, N. Garland, D. Myers, M. Wilson, F. Garzon, D. Wood, P. Zelenay, K. More, K. Stroh, T. Zawodzinski, J. Boncella, J.E. McGrath, M. Inaba, K. Miyatake, M. Hori, K. Ota, Z. Ogumi, S. Miyata, A. Nishikata, Z. Siroma, Y. Uchimoto, K. Yasuda, K.I. Kimijima, N. Iwashita, Chem. Rev. 107 (2007) 3904

[3] F.A. De Bruijn, V.A.T. Dam, G.J.M. Janssen, Fuel Cells 8 (2008) 3.

[4] J. Healy, C. Hayden, T. Xie, K. Olson, R. Waldo, A. Brundage, H. Gasteiger, J. Abbott, Fuel Cells 5 (2005) 302
[5] D.E. Curtin, R.D. Lousenberg, T.J. Henry, P.C. Tangeman, M.E. Tisack, J. Power Sources 131 (2004) 41

[6] F.M. Collette, C. Lorentz, G. Gebel, F.J. Thominette, Membr. Sci. 330 (2009) 21.

[7] F.M. Collette, F. Thominette, H. Mendil-Jakani, G.J. Gebel, J. Memb. Sci., submitted for publication.

[8] J.L. Qiao, M. Saito, K. Hayamizu, T. Okada, J. Electrochem. Soc. 153 (2006) A967.

[9] I. Merdas, F. Thominette, J. Verdu, Polym. Degrad. Stab. 79 (2003) 419. 